demonstrated ${ }^{10}$ in the fruitfly Drosophila. This receptor is not, however, recognized by anti-receptor antisera directed against insulin receptors of human placenta or rat liver, a feature that suggests structural differences between the insect and mammalian receptors. In regard to studies of this type, it is relevant to note that the considerable variation in the peptides of the insulin family that exists presumably as a result of evolutionary selection pressures, is likely to be matched by an equal variation of the receptors. As an example of this, the structural homologies shared by insulin and IGF peptides are paralleled by a structural homology of the receptors for insulin and IGF-1 (ref. 11).

Insulin is, perhaps, the most actively researched of all biological molecules and the variety and number of problems associated with it seem to increase exponentially with every new advance that is made. The realization that invertebrates as well as vertebrates are custodians of this molecular species adds a further challenging dimension to the problem of insulin.

Alan Thorpe and Hanne Duve are in the School of Biological Sciences, Queen Mary College, University of London, Mile End Road, London EI $4 N S, U K$.

\title{
Oceanography
}

\section{Stirrings in the abyss}

\section{Nick McCave}

THE notion that deep waters run steadily, if not still, receives another knock on the head from the work of Gross et al. on abyssal storms in the North Atlantic reported on page 518 of this issue ${ }^{1}$. It was the prevailing view 15 years ago, most eloquently put by Heezen and Hollister ${ }^{2}$, that "the warm water sphere protects and isolates the abyss from the more familiar forces of weather, leaving... the thermohaline currents which spread and mix from pole to pole, the rotation of the earth which deflects these currents to the side of the basin and the tides which gently, but incessantly, caress the abyssal waters". Not that this steady thermohaline flow was everywhere seen as gentle, for several places, particularly straits and passages, displayed striking photographic evidence of current scour ${ }^{2}$ (see figure). Gross and co-workers document with detailed velocity, turbulence and turbidity measurements one of several significant perturbations of the mean flow called deep-sea storms ${ }^{3}$.

Gross et al. worked in the

The effect of a deep-sea storm in the North Atlantic. Left, taken during a storm on 29 November 1985. Small features have been hydraulically smoothed by the flow. Five days later (right) the flow has slowed and the bed is roughened on the smallest scale $(1-2 \mathrm{~cm})$ by animal tracking, but is smoothed on larger scales by the moderate flow from the north-west. (Courtesy T.F. Gross and A.J. Williams III). highest surface $K_{\mathrm{E}}$ found in the Gulf Stream. This led to the suggestion that the episodes of high-speed bottom currents which stir up the bed ('storms') are related to downwards propagation of eddy energy from the upper ocean ${ }^{4.5}$.

Recent current-meter results from the highly energetic east Australian Tasman Sea region also show high-speed bottom currents related to the passage of surface warm-core rings, and sediment bedforms, uous record of turbulence and turbidity for a year at five levels above the bed in the deep ocean $5 \mathrm{~km}$ down. Such a record has not ever been obtained, even in shallow water. It will be instructive to compare it with other records of planetary boundary layers on land, over the sea and under ice. Records of the deep sea were somewhat easier to obtain because there is no contamination by surface waves, thus permitting in situ data analysis and compression. Only the time-averaged components of the Reynolds stress are stored rather than the four separate data sets accumulated at $2 \mathrm{~Hz}$ by each current sensor. The storm Gross et al. report with a maximum speed of $22 \mathrm{~cm} \mathrm{~s}^{-1}$ is relatively modest (although earlier reports ${ }^{11}$ of speeds up to $74 \mathrm{~cm} \mathrm{~s}^{-1}$ are in error by a factor of two), but it produces a very high turbidity. Thus, reported turbidities of up to $12,000 \mathrm{mg} \mathrm{m}^{-3}$ are plausibly accounted for by bottom-flow speeds up to $40 \mathrm{~cm} \mathrm{~s}^{-1}$. Note that the critical erosion speeds at the onset of the storm implicit in Fig. 2 of Gross et al. on page 520 are $14 \mathrm{~cm} \mathrm{~s}^{-1}$ ( $4.5 \mathrm{~m}$ above bottom) or a shear velocity of $0.68 \mathrm{~cm} \mathrm{~s}^{-1}$.

There are many areas of the deep sea where speeds in excess of $14 \mathrm{~cm} \mathrm{~s}^{-1}$ are achieved at least intermittently. The importance of this observation lies in the uses that can be made of the deep-sea bed. In waste disposal, for example, it emerges that there are some areas from which particulate materials will be raised up and dispersed far and wide, whereas other areas will be more retentive. For the installation of listening devices on the sea bed, the results warn which areas would alternately scour and blanket them with deposits of mud. There may even be implications for the routing of deep-sea cables: turbidity currents, slumps and debris flows have normally been seen as their principal enemies, but it now seems to be possible that some stormy areas of the abyss could be worth giving a miss. high-energy benthic boundary-layer both indicating (temporary) strong flow experiment (HEBBLE), which was counter to that expected for the regional designed to examine interactions between thermohaline flow ${ }^{6.7}$. These observations deep flows and sediment beds in a region and those of HEBBLE indicate that satelexpected to be dominated by steady, swift currents towards the south-west. Although the authors did indeed find swift currents, they were markedly unsteady. The work of several physical oceanographers compiled by Schmitz ${ }^{4}$ and Weatherleys shows that the eddy kinetic energy $\left(K_{\mathrm{r}}\right.$, variance of the current velocity) is high at depths greater than $4,000 \mathrm{~m}$ in part of the western North Atlantic. The zone of high abyssal $K_{\mathrm{E}}$ appears to underlie directly the region of lite and drift maps of surface eddy kinetic energy $^{8.9}$ will be a useful guide for searches for energetic, eroding bottom flows. The most distinctive region in this respect is the circumpolar Southern Ocean, which may thus be not only the 'lung' of the oceans but also the source of most turbid bottom water"

The achievements of Gross et al. reported in this issue and previously are noteworthy in terms of instrumentation. The authors have obtained a near contin-
1. Gross, T.F., Williams, A.J. III \& Nowell, A.R.M. Nature 321. 518-521 (1988)

2. Heezen, B.C. \& Hollister, C.D. The Face of the Deep (Oxford University Press, 1971)

3. Hollister, C.D. \& McCave, I.N. Nature 309, 220-225 (1984).

4. Schmitz, W.L. J.mar.Res 40,500-536(1984)

5. Weatherley, G.L. J.mar.Res. 42, 289-301 (1984)

6. Mulhearn. P.J. et al. Deep Sea Res. 33, 1563 (1986)

Jenkins. C.J. et al. Ocean Sci.Inst. Rep. 18 (University of Sydney, 1986).

8. Cheney, R.E. et al. J.geophys.Res. 88, 4343-4354 (1983)

9. Daniault, N. \& Menard, Y. J.geophys.Res. 90, $11877-$ 11889 (1985)

10. McCave, I.N. Neth.J.Sea Res. 20, 167-181 (1986). 11. Richardson. M.J. et al. Science 213, 887-888 (1981)

Nick McCave is Woodwardian Professor of Geology in the Department of Earth Sciences, University of Cambridge, Cambridge CB2 $3 E Q, U K$. 